\title{
Bepalers van watersekuriteit vir landelike huishoudings: Empiriese bewyse uit die Melani- en Hamburg-gemeenskappe, Oos-Kaap, Suid-Afrika
}

\section{Outeurs: \\ Thulani Ningi ${ }^{a}$ \\ Amon Taruvinga \\ Leocadia Zhou ${ }^{b}$ \\ Saul Ngarava ${ }^{b}$ \\ Affiliasies: \\ aDepartement van Landbou- Ekonomie en -Voorligting, Universiteit van Fort Hare, Alice, Suid-Afrika \\ bWetenskaplike Sentrum vir Risiko en Kwesbaarheid, Universiteit van Fort Hare, Alice, Suid-Afrika \\ Korresponderende outeur: Thulani Ningi \\ E-pos: \\ Thulaniningi96@gmail.com \\ Datums: \\ Ontvang: $\quad 08 / 09 / 20$ \\ Aanvaar: $\quad 12 / 04 / 21$ \\ Gepubliseer: 27/07/21}

Hoe om hierdie artikel aan te haal:

Thulani Ningi, Amon

Taruvinga, Leocadia Zhou,

Saul Ngarava, Bepalers van watersekuriteit vir landelike

huishoudings: Empiriese

bewyse uit die Melani- en

Hamburg-gemeenskappe,

Oos-Kaap, Suid-Afrika,

Suid-Afrikaanse Tydskrif

vir Natuurwetenskap en

Tegnologie 40(1) (2021).

https://doi.org/10.36303/

SATNT.2021.40.1.802

An English copy of this paper is available online at http://www.satnt.ac.za/ index.php/satnt/article/ view/802

\section{Kopiereg:}

(C) 2021. Authors.

Licensee: Die SuidAfrikaanse Akademie vir Wetenskap en Kuns. Hierdie werk is onder die Creative Commons Attribution License gelisensieer.
Skoon en veilige water om te drink is noodsaaklik vir die mens se welstand. Die meeste mense in landelike gebiede het egter steeds nie toegang tot skoon en veilige water nie. Hierdie studie het die bepalers van die watersekuriteitsstatus vir landelike huishoudings uit die Melani-binnelandse en Hamburgse kusgemeenskappe in die Oos-Kaap Provinsie, Suid-Afrika, beraam. Die Waterarmoede Indeks (WPI) is gebruik om die watersekuriteitsstatus van huishoudings in die twee gemeenskappe te bereken, terwyl die Tobitregressiemodel gebruik is om die belangrikste faktore wat die huishoudelike watersekuriteitsstatus beïnvloed, te ondersoek. Die bevindings toon dat watersekuriteit in die studiegebiede verskraald is, hoofsaaklik as gevolg van die onbeskikbaarheid van waterbronne en die tyd wat daar geneem word om water in te samel. Die Tobit-regressie resultate het aan die lig gebring dat faktore soos die betaling vir water, die tipe toilet wat gebruik word, en die tyd wat spandeer word om water in te samel, huishoudings se watersekuriteit in die studiegebiede bepaal. Daarom beveel die artikel beleid aan wat die volgende verbeter: die bekostigbaarheid van water, toegang tot spoeltoilette wat nie met water werk nie, en om te verseker dat kraanwater op korter afstande beskikbaar is.

Sleutelwoorde: watersekuriteit, waterarmoede-indeks, Hamburg-gemeenskap, Melanigemeenskap

Determinants of water security for rural households: Empirical evidence from Melani and Hamburg communities, Eastern Cape, South Africa: Clean and safe water to drink is essential for human wellbeing. However, most people in rural areas still lack access to clean and safe water. This study estimated the determinants of the water security status for rural households from Melani-inland and Hamburg-coastal communities in the Eastern Cape Province, South Africa. The water poverty index (WPI) was used to calculate the water security status of households in the two communities, while the Tobit regression model was used to investigate the main factors affecting household water security status. The findings show that water security in the study areas is meagre, mainly due to the unavailability of water resources and the time that is taken to collect water. The Tobit regression results revealed that factors such as paying for water, type of toilet used, and time spent collecting water determine households' water security in the study areas. Therefore, the paper recommends policy options that improve: the affordability of water, access to non-water using flush toilets, and ensuring tap water is available at shorter distances.

Keywords: water security, water poverty index, Hamburg community, Melani community

\section{Inleiding}

Skoon en veilige water om te drink en sanitasie is baie belangrik vir menslike gesondheid en welstand. Die belangrikheid van water en sanitasie word beklemtoon in die Agenda 2030, Doelwitte vir Volhoubare Ontwikkeling (Doelwit 6), met die klem op die belangrikheid van beskikbaarheid en volhoubare bestuur van water en sanitasie vir almal (Akinyemi et al., 2017). Tans het ongeveer 2,2 miljard mense in die wêreld nie toegang tot veilige water nie, en na raming sal die vraag na water verdubbel teen 2030 (UN-Water, 2019). Terselfdertyd sal die wêreldbevolking na verwagting in die volgende 50 jaar met drie miljard of meer groei, veral in ontwikkelende lande (Jury en Vaux, 2005). Tot op hede het die meerderheid huishoudings in ontwikkelende lande nie toegang tot veilige en skoon drinkwater vir hul bestaan nie (Government of Canada, 2017). 
Die onbeskikbaarheid van water op 'n huishoudelike vlak in plattelandse gebiede hou risiko's vir menslike welstand in, asook vir sulke sektore soos voedselsekuriteit en landbou wat bykans $70 \%$ van alle varswater benut (Mabhaudi et al.,GC, 2017).

Afhangend van die konteks, kan die definisie van watersekuriteit verskillende betekenissie inhou. Vanuit ' $n$ landbouperspektief verwys dit na insette in produksie en voedselsekuriteit, terwyl dit vanuit ' $n$ water hulpbron perspektieffokus op waterskaarsteen voorsieningsekerheid. Beleid rakende watersekuriteit is onder meer om kwesbaarheid vir hidrologiese wisselvalligheid te verminder, interdissiplinêre skakeling te bewerkstellig(voedsel, energie, klimaat, ekonomiese en menslike veiligheid) en volhoubare ontwikkeling te fasiliteer(Cook en Bakker, 2012). Met die ontwikkeling van aanwysers vir watersekuriteit, benadruk Jensen en $\mathrm{Wu}$ (2018) dat watersekuriteitsaanwysers onderverdeel kan word in indekse soos hulpbronne, toegang, risiko's en bestuur. Aanwysers vir bronne verwys na beskikbaarheid (beskikbaarheid van waterbronne, opbergingsvermoë vir water), diversiteit (diversiteit van watervoorsiening) en kwaliteit (rou watergehalte). Toegang sluit in kapasiteit (watervoorsieningskapasiteit, watervoorsieningsdekking), volhoubaarheid van dienste (kosteverhaling van watervoorsienings) en bekostigbaarheid (watertarief). Risiko's dui weer op oorstromings (vloedfrekwensie en vloedskade) en die openbare gesondheidsgevaar (toegang tot water, sanitasie en voorvalle van water kontaminasie). Bestuur sluit strategiese beplanning in (of regerings / instellings water kan voorsien) en rampbestuur en -regulering.

In die Afrika-konteks, veral in landelike gebiede, het die meeste huishoudings nog nie toegang tot veilige en skoon water om te drink nie (Heijnen et al., 2014; UNICEF en WHO, 2015). Landelike Afrika bly agterweë met die voorsiening van veilige drinkwater aan byna 300 miljoen van sy inwoners (Hope et al., 2020). Verder is daar 'n gebrek aan ' $n$ analitiese en diagnostiese raamwerk vir die beoordeling van watersekuriteit in Afrika (Holmatov et al., 2017). Ongeveer 14 lande in Afrika, insluitend Suid-Afrika, het nie toegang tot voldoende water nie, met nog 11 lande wat na verwagting teen 2025 by hierdie groep sal aansluit (World Wide Fund, 2012). Alhoewel 'n studie in Suider-Afrika, (Holmatov et al., 2017) aangedui het dat watersekuriteit in die Suider-Afrikaanse Ontwikkelingsgemeenskap (SADC) die beste is in die Seychelles en Suid-Afrika, en die laagste vir Malawi en Madagaskar, ontbreek dit steeds plattelandse gemeenskappe aan skoon water vir hulle voortbestaan. Klimaatsverandering, sosio-ekonomiese ontwikkeling, bevolkingsgroei en oneffektiewe bestuur word geïdentifiseer as elemente wat die watersekuriteit beïnvloed (Zawahri, 2017). Ongeveer $80 \%$ van die siektes in Afrika hou verband met die onbeskikbaarheid van water en swak sanitasie (Ahmad en Satter, 2010; GC, 2017). Skoon en veilige drinkwater en sanitasie is daarom noodsaaklike behoeftes in die gesondheid en welstand van die mens. Die verbetering van toegang tot skoon en veilige drinkwater vir plattelandse gemeenskappe sal dus waterverwante siektes verminder. WaterAid (2017) getuig dat die verbetering van toegang tot skoon en veilige water, 'n noodsaaklike onderdeel is van 'n geïntegreerde benadering om armoede te verlig, gesondheid te verbeter en hongersnood te verlaag. Alhoewel die Suid-Afrikaanse regering water erken as ' $n$ belangrike bron vir menslike welstand en pogings aanwend om skoon en veilige drinkwater te voorsien vir huishoudings (DWA, 2004; Hardberger, 2005), het ongeveer vyf miljoen landelike Suid-Afrikaners steeds geen toegang tot skoon en betroubare drinkwater nie (StatsSA, 2016). Die literatuur dui aan dat Suid-Afrika 'n baie waterskaars land is met hoë druk op beperkte waterbronne (Sershen et al., 2016). Dit is een van die 49 droogste lande, en ekonomiese groei word vertraag deur onvoldoende toegang tot drinkwater en sanitasie (Meissner et al., 2018). Volgens Statistiek Suid-Afrika (2016), het slegs $44,4 \%$ van alle huishoudings toegang tot geleide water in hul huis, 30\% in hul erf, 15,5\% tot ' $n$ punt buite die erf, en $10 \%$ is heeltemal sonder toegang tot water. In die poging om watersekuriteit vir almal in Suid-Afrika te verseker, is goed gedokumenteerde waterwetgewing wat die waterbeweging rakende mense en die omgewing bepaal, beskikbaar gestel (WWF-SA, 2017). Die waterwetgewing impliseer dat doeltreffende watergebruik en bestuur van hierdie beperkte waterbronne dringend is om volhoubaarheid te bevorder (Njoko en Mudhara, 2017). Te oordeel aan die uiteenlopende waterverwante kwessies in Suid-Afrika, is dit duidelik dat watersekuriteit ' $n$ dringende maatreël is wat die regering moet aanspreek (Soyapi, 2017). Verskeie outeurs soos Ngarava et al. (2019), Meissner et al. (2018) en Rodda et al. (2016) het studies gedoen oor watersekuriteit in Suid-Afrika, wat gemengde resultate op die vlak van watersekuriteit aandui.

Huishoudelike sosio-ekonomiese eienskappe het min aandag gekry in terme van watersekuriteit op huishoudelike vlak in Suid-Afrika (Sinyolo et al., 2014). 'n Klein aantal studies deur Ngarava et al (2019) en Sinyolo en Mudhara (2014), het probeer om op die sosio-ekonomiese aspekte van watersekuriteit in Suid-Afrika te fokus. Die meeste van hierdie studies was egter óf homogeen (Ngarava et al. 2019), wat op die hele land as geheel gefokus het, óf ruimtelik anders gefokus op sekere gebiede, soos 'n studie deur Meissner et al. (2018), wat na Sekhukhune en eThekwini Plaaslike Munisipaliteite gekyk het. 'n Studie van Rodda et al. (2016), fokus op 'n plaaslike besluitnemingsvlak. Om 'n beter begrip te verkry van hoe watersekuriteit vir huishoudings verseker kan word, is n gebied wat empiriese navorsing vereis (Young et al., 2019). Verder het Sinyolo et al. (2014) dit gestel dat daar beperkte wetenskaplike kennis is oor die belangrike faktore wat watersekuriteit beïnvloed, veral op huishoudelike vlak. Rhodes en Mckenzie (2018) het getuig dat, ten einde die regering in staat te stel om die faktore wat die waterkoste laat styg, te kan vermy, dit nodig is om eers faktore te verstaan wat die huishouding se toegang tot water beïnvloed. 
Tot op hede is daar in Suid-Afrika beperkte klem gelê op die begrip van die impak van sosio-ekonomiese faktore op die huishouding se watersekerheid (Rhodes en McKenzie, 2018). Min studies het probeer om hierdie roete te volg. Ngarava et al. (2019) het 'n geslagsperspektief in ag geneem met die kyk na watersekuriteitsstatus van gesinne met vroulike hoofde in Suid-Afrika. Die studie het bevind dat huishoudings met vroulike hoofde dinamies is in hul blootstelling, sensitiwiteit en aanpassingsvermoë vir wateronsekerheid. Vroue het toegang tot kapasiteitsbou en bemagtiging in $\mathrm{n}$ welvaartsgenerasie nodig. Dit behels noodwendig ' $n$ verbetering in hulle watersekerheidstatus wat behaal kan word deur hulle toegang tot behandelde water te verbeter, en algemene infrastruktuur verbetering (Ngarava et al, 2019).

Sinyolo en Mudhara (2014) bevind dat sosio-ekonomiese faktore soos die ouderdom van die boer, die inkomste buite die boerdery, opleiding, ligging en lidmaatskap aan verenigings, betekenisvol was om die watersekuriteit te verhoog. Faktore soos konflik was ook belangrik in die vermindering van watersekuriteit. In 'n studie deur Sharaunga en Mudhara (2016), wat op besproeiïng-skemas gefokus het, is faktore aangetoon soos die ouderdom van die boer, toegang tot grond, en lidmaatskap van die vereniging wat die watersekuriteit in Suid-Afrika verminder het.

Verskeie faktore is uit die literatuur geïdentifiseer as 'n invloed op watersekuriteit. Dit val uiteen in fisiese/ infrastruktuur-, institusionele en sosio-ekonomiese kategorieë (Sharaunga en Mudhara, 2016). Fisiese/infrastruktuurfaktore wat die watersekuriteit beïnvloed, sluit die hidrologiese patrone, topografiese kenmerke, en kunsmatige fasiliteite vir die opberging en vervoer van water in. Institusionele faktore soos tradisionele wette, statutêre wette en ander vorme van ongelykheid verhoed toegang tot water. Sosio-ekonomiese faktore sluit in geslag, inkomste, samelewingsposisie, kultuur, en tradisie. Volgens Hinojosa et al. (2018) is veralgemenings oor die bepalers van watersekuriteit egter nie ideaal nie. Spesifieke sosiale en omgewingsfaktore, asook die persepsies rakende watersekuriteit, moet verander word.

In die Oos-Kaap Provinsie van Suid-Afrika het verskeie geleerdes bevind dat landelike gemeenskappe wateronsekerheid in die gesig staar as gevolg van klimaatsverandering, wat 'n aansienlike impak op die verspreiding van reënval, stroomvloei, watergehalte, soutindringing en droogte het (Grecksch, 2015; Afrika, 2012). As gevolg hiervan staar landelike gemeenskappe in die Oos-Kaap, wat Hamburg insluit, groot watertekorte in die gesig, wat veroorsaak dat inwoners water uit plaaslike damme trek of hulself tot een bad per week beperk om die beskikbare water te bespaar (Jacob, 2018). Volgens 'n inwoner wat 'n agentskap in Hamburg bestuur, het die gebiede in 2018, 19 keer wateronderbrekings ondervind, sonder dat die munisipaliteit dit verduidelik het (Jacob, 2018). Hierdie studie het daarom gepoog om die watersekuriteit in twee verskillende Oos-Kaapse gemeenskappe vas te stel, naamlik Melani-binneland en Hamburg-kusgebied. Meissner et al. (2018) het 'n soortgelyke studie uitgevoer, wat gefokus het op twee verskillende munisipaliteite in Suid-Afrika (Sekhukhune, die binnelandse, droër en sosio-ekonomies 'n landelike munisipaliteit, en eThekwini, wat aan die kus en verstedelik is). Verder het die studie ' $n$ kwalitatiewe ontwerp gebruik, met behulp van onderhoude met sleutel informante en fokusgroepe, gerig op gemeenskapsmeningleiers en besluitnemers. Hierdie studie sal anders wees aangesien dit op verskillende munisipaliteite sowel as op verskillende mikrohuishoudingsvlakke fokus.

\section{Navorsingsmetodologie Die studiegebiede}

Hierdie studie is in die Keiskamma-opvanggebied uitgevoer, asook die Keiskammarivier se hoofstrome in die OosKaap, Suid-Afrika. Die Keiskamma-opvanggebied en die bolope van die Keiskammarivier is geleë in die Oos-Kaap Provinsie van Suid-Afrika onder die groter Amatola (Mhangara, Kakembo en Lim, 2011) gebied. In die opvanggebied is twee verskillende gemeenskappe doelgerig gekies op grond van hul kwesbaarhede met betrekking tot die natuurlike hulpbron, naamlik Melani-binnelandse en Hamburgse landelike gemeenskappe.

Hamburg is ' $n$ klein landelike gebied in die Ngqushwa plaaslike munisipaliteit. Hamburg is naby die Keiskammariviermonding geleë, waar die Keiskamma-rivier in die Indiese Oseaan stroom (33 $13^{\circ} 26,88^{\prime \prime} \mathrm{S}, 27^{\circ} 28^{\prime} 30$ " O) (Martens, 2015). Hamburg bestaan uit gemeenskaplike, private en staatsgrond en is verbind met die R72-pad met 'n $14 \mathrm{~km}$ grondpad (Afrika, 2012). Die naaste stedelike gebied is dié van Peddie, met die grootste stedelike gebied Oos-Londen, wat $90 \mathrm{~km}$ weg is (Martens, 2015).

Die studie het ook gefokus op die Melani-binnelandse gemeenskap om die belangrikste drywers van wateronsekerheid vir landelike huishoudings van 'n ander omgewing as die van die Hamburg-kusgemeenskap te ondersoek. Melani is ' $\mathrm{n}$ dorpie, ongeveer $12 \mathrm{~km}$ noord van Alice, in die Oos-Kaap. Die dorpie is geleë in die Raymond Mhlaba Plaaslike Munisipaliteit (RMLM), voorheen bekend as Nkonkobe Plaaslike Munisipaliteit (NLM). Die dorpie is ook langs die Keiskammarivier ( $32^{\circ} 43^{\prime} 29^{\prime \prime} \mathrm{S}, 27^{\circ} 07^{\prime} 35^{\prime \prime} \mathrm{O}$ ) geleë. Die plaaslike munisipaliteit beslaan $3725 \mathrm{~km} 2$ en is langs die R63-weg in die Amatole-distriksmunisipaliteit geleë (Ngcobo, 2017).

\section{Teoretiese raamwerk}

Die studie het gefokus op die bepalers van watersekuriteit vir huishoudings in landelike gebiede. In hierdie studie word watersekuriteit gedefinieer as betroubare, en volhoubare toegang tot water deur mense en die gemeenskappe om aan hul daaglikse behoeftes te voldoen (Reddy, 2002). Volgens McGarvey et al. (2008), speel die huishouding se 
sosio-ekonomiese faktore ' $n$ deurslaggewende rol in die verbetering van die watertoegang van die huishouding, soos om aangelegde water te hê, oop putte of beter sanitasie. Navorsing dui aan dat die huishouding se vermoë om vir water te betaal ook ' $n$ kritieke rol in sommige gemeenskappe speel vir beter waterlewering (Nocholas et al., 2019). In die meeste landelike gemeenskappe betaal huishoudings egter nie vir watervoorsiening nie (Mothetha et al., 2013; Nkuna en Ngorima, 2011). Die huidige studie meet daarom watersekuriteit op grond van die totale beskikbare waterbronne en die tyd geneem om water te versamel.

Om die faktore wat die watersekuriteit beïnvloed te verstaan, is die Sustainable Livelihood Framework (SLF) aanvaar. Die raamwerk word meestal gebruik om minderbevoorregte lewensonderhoud te verstaan en te ontleed (Carney, 1999). Verskeie geleerdes stel dit dat die raamwerk 'n nuttige metode is om na faktore te kyk wat die armes kan ontneem om ' $n$ beter bestaan vir hulself te maak (Donohue en Biggs, 2015; Carney, 1999). Scoones (2009) stel voor dat arm huishoudings in staat moet wees om skokke en spanning wat die omgewing oplewer, te kan hanteer om hulle lewensonderhoud te kan volhou en om die bates in stand te hou terwyl hulle natuurlike hulpbronne soos water in ag neem. Volgens Donohue en Biggs (2015), impliseer 'n benadering vir volhoubare lewensonderhoud dat armoede nie net gebaseer is op die tekort aan inkomste nie, maar ook op ' $n$ multidimensionele konsep wat ander aspekte in gedagte hou, soos bekostigbaarheid van onderwys en gesondheidsorg. Die raamwerk fokus ook op 'n huishoudelike vlak en bates wat die huishouding beheer, wat beïnvloed word deur eksterne faktore en skokke soos droogte en klimaatsverandering (Scoones, 1998).
Die raamwerk is nuttig om sosio-ekonomiese en omgewingskwessies te korreleer (Brocklesby en Fisher, 2003). Figuur 1 gee 'n samevatting van die benadering tot volhoubare lewensonderhoud (Chambers and Conway, 1991).

Chambers and Conway (1991) stel voor dat die begrip "lewensonderhoud" van huishoudings geformuleer word uit finansiële-, sosiale-, fisiese-, menslike- en natuurlike kapitaal. Hiervolgens word finansiële kapitaal gedefinieer as die beskikbaarheid van aandele, insluitend spaar-, pensioen- en looninkomste (Martens, 2015). Sosiale kapitaal word gedefinieer as die verhoudings en netwerke wat mense in staat stel om saam te werk. Fisiese kapitaal is hoofsaaklik die noodsaaklike infrastruktuur waarop mense vir hul lewensonderhoud afhanklik is, soos watervoorsiening en sanitasie. Menslike kapitaal word gedefinieer as die vaardighede en die vermoë van mense om verskillende lewensonderhoudstrategieë na te streef, terwyl natuurlike kapitaal gedefinieer word as die natuurlike hulpbronne wat lewe onderhou (water). Water is daarom een van die belangrikste natuurlike hulpbronne wat huishoudings op die platteland help om hul in hulle lewensonderhoud te voorsien. Op grond van hierdie agtergrondinligting, word die benadering vir volhoubare lewensbestaan gebruik om die sosio-ekonomiese faktore wat natuurlike hulpbronne soos water beïnvloed, te verbind. Om hierdie doel te bereik, beskryf die referaat die watersekuriteitsstatus en ondersoek die faktore wat watersekuriteit in die studiegebied beïnvloed.

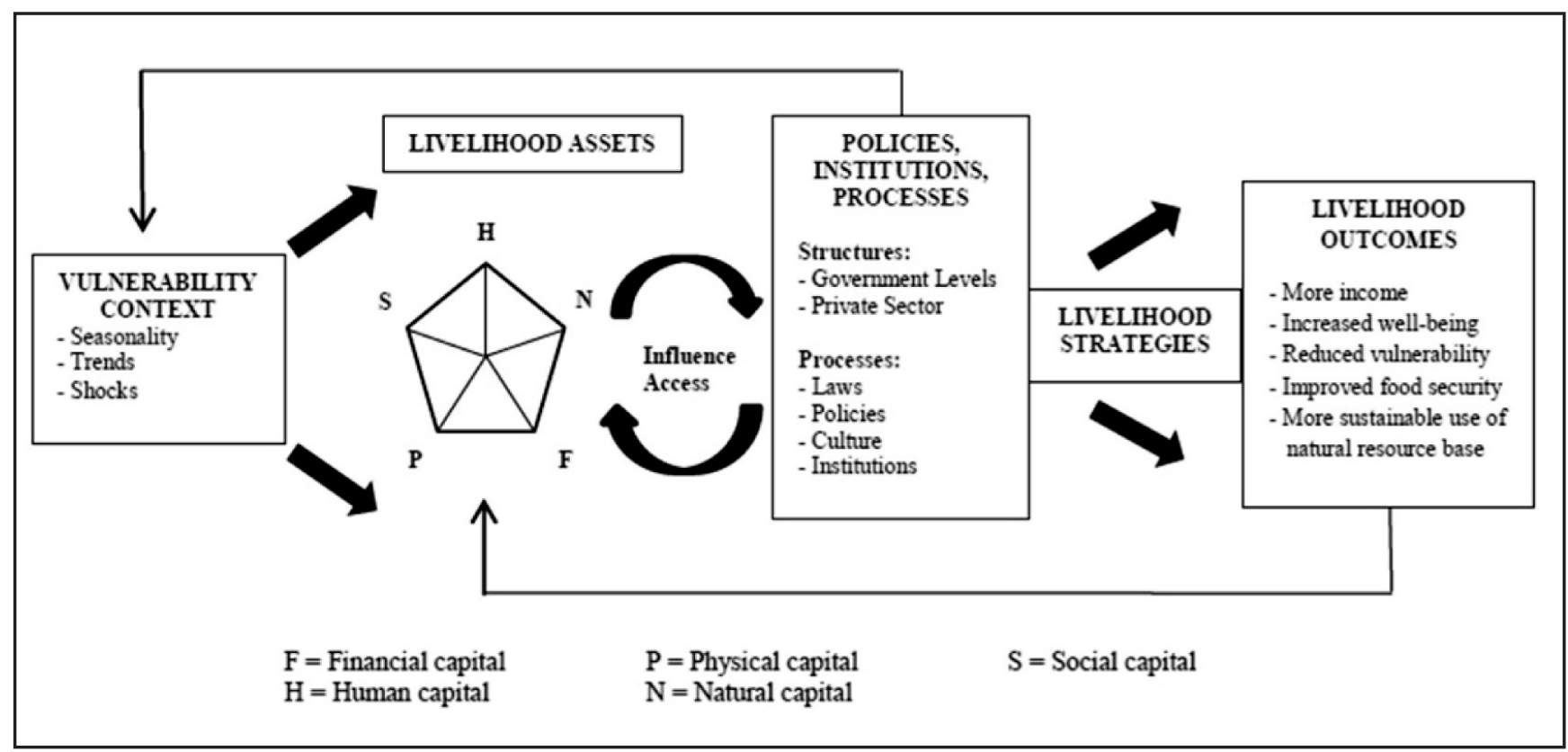

FIGUUR 1: Raamwerk vir volhoubare lewensonderhoud Bron: Solesbury (2003) 


\section{Monstermetode en steekproefgrootte}

Die studiegebiede is doelgerig gekies op grond van die kwesbaarheid van die waterbronne in die omgewing. Volgens die voormalige Nkonkobe-munisipaliteit (2012), het die Melani-gemeenskap ' $n$ bevolking van 500 huishoudings, en Hamburg het 'n totale bevolking van 454 huishoudings (StatsSA, 2013), wat 'n gekombineerde getal van 945 huishoudings uitmaak. Daar bestaan egter 'n moontlikheid van groei of inkrimping van die bevolking tussen die aangeduidejare tot op hede. Om'n vertrouensvlak van $95 \%$ met ' $n$ foutvlak van $5 \%$ te verkry, is 283 huishoudings die laagste aanvaarbare getal. Daarom het die studie ewekansig 283 huishoudings gekies vir direkte ondervraging, deur gebruik te maak van vraelyste. Die studie het 141 huishoudings van Melani en 142 van Hamburg gekies vir 'n totaal van 283 huishoudings.

Die steekproefgrootte is afgelei van die onderstaande formule, na aanleiding van Israel (2013).

$$
\mathrm{n}=\mathrm{N} 1+\mathrm{N}(\mathrm{e}) 2
$$

Waar $\mathrm{n}$ die steekproefgrootte is, is $\mathrm{N}$ die populasiegrootte en e die vlak van juistheid. Die toepassing van hierdie formule met die bekende aantal huishoudings en 'n foutmarge van $5 \%$ is dus:

$$
\begin{aligned}
& n=9451+945(0.05) 2 \\
& =283 \text { huishoudings }
\end{aligned}
$$

\section{Bronne van data en metodes om data te ver- samel}

'n Dwarsdeursnee-navorsingsontwerp is gebruik om inligting in te samel van die 283 lukraak-geselekteerde huishoudings in die twee studiegebiede, naamlik die Hamburg-kusgebied en Melani-binnelandse gebied. Aangesien die populasie relatief homogeen was, is die steekproefgrootte as groot genoeg beskou om geldigheid te verseker. Kwantitatiewe data is vir hierdie studie gebruik. 'n Semigestruktureerde vraelys is opgestel vir individuele onderhoude. Die vraelys is vooraf getoets en dienooreenkomstig gewysig voordat dit aan respondente toegedien is. Die werklike primêre gegewens is in Junie 2019 deur vyf opgeleide opsommers van albei gemeenskappe versamel. Die vraelys is saamgestel uit inligting oor die basiese kenmerke van die huishoudelike hoof, soos geslag, ouderdom, huwelikstatus en opvoedingsvlak.

\section{Metodes van data-analise}

\section{Die meting van watersekuriteitsstatus}

Die studie het die Waterarmoede-indeks (WPI) gebruik om die vlak van watersekuriteit vir elke respondent in die studiegebiede te bereken. Die huishoudelike watersekuriteitsindeks bestaan uit die volgende veranderlikes:
- Beskikbaarheid van water,

- Toegang tot veilige water,

- Skoon sanitasie, en

- $\quad$ Tyd geneem om huishoudelike water op te vang.

Die WPI word soos volg gegee: (Sullivan, 2002)

$$
\text { WPI }=w a A+w s S+w t 100-T
$$

Waar A: die aangepaste beskikbaarheid van water (AWA) as persentasie is. Dit word bereken op grond van die beskikbaarheid van grondwater en oppervlakwater, verbandhoudend met ekologiese waterbehoeftes, en 'n basiese menslike behoefte en alle ander huishoudelike eise sowel as eise van die landbou; $\mathrm{S}$ : is huishoudelike toegang tot veilige drinkwater en sanitasie (\%); T is die indeks (tussen 0 en 100) wat die tyd en moeite voorstel om water vir huishoudelike gebruik in te samel. Die finale vlak van die WPI bestaan uit die gewigte wat aan elke komponent van die indeks gegee word, sodat ().wa,ws and wtwa+ws+wt=1

Aangesien A, S en T almal tussen 0 en 100 en tussen 1 en 0 gedefinieer word, is die behoefte om die formule soos volg te wysig om 'n WPI-waarde tussen 0 en 100 te produseer:

$$
\text { WPI=13(waA+wsS+wt100-T) }
$$

Na studies soos (Sullivan, 2002; van der Vyver, 2013;) sal die lineêre indeks soos volg geïnterpreteer word: as WPI = 100 , is die huishouding waterbeveilig. As WPI dan $=0$ is, beteken dit dat die huishouding wateronseker is.

\section{Tobit-regressiemodel}

Die Tobit-regressiemodel is gebruik om faktore wat die huishoudelike watersekuriteitsstatus beïnvloed, te identifiseer. Die watersekuriteitsindeks is dan gebruik as ' $n$ afhanklike veranderlike op die Tobit-regressiemodel om die faktore wat die huishoudelike watersekuriteitsstatus in die studiegebiede beïnvloed, te evalueer.

Die Tobit-regressiemodel is soos volg geskat (Maziya et al., 2017);

$$
Y_{1}=\beta+\beta X_{1}+e_{I}
$$

Waar $Y_{I}=$ WPI i: $\beta$ 。 die konstante term in die model; $\beta=$ 'n vektor van die veranderlike koëffisiënte; en $\mathrm{e}_{\mathrm{I}}=$ foutterm. Die Tobit-regressiemodel is as toepaslik beskou, aangesien dit rekening hou met die deurlopende maar ingekorte aard van die afhanklike veranderlike $(\min =0 ;$ maks $=100)$. Die 'Akaike's Information Criterion (AIC) en die Bayesian Information Criterion (BIC) is gebruik om die geskiktheid van die model met eenvoudige lineêre regressie te vergelyk. $\mathrm{YI}=0 \mathrm{eI}$ 


\section{Veranderlikes en literatuuroorsig}

TABEL 1: Veranderlikes wat in die Tobit-model gebruik word

\begin{tabular}{|c|c|c|}
\hline Veranderlikes & Beskrywing & Literatuur \\
\hline $\begin{array}{l}\text { Afhanklike veranderlike } \\
\text { WPI }\end{array}$ & $\begin{array}{l}\text { Waterarmoede-indeks ( } 0=\text { waterarm, } 100= \\
\text { waterbeveilig) }\end{array}$ & $\begin{array}{l}\text { Waterarmoede-indeks (WPI) is 'n lineêre veranderlike wat gemeet word as } \\
\text { 'n persentasie tussen } 0 \text { en } 100 \text { van die huishouding se toegang tot skoon } \\
\text { water om te drink en vir sanitasie doeleindes, die tyd wat dit benodig om } \\
\text { water in te samel en die beskikbaarheid van waterbronne. }\end{array}$ \\
\hline $\begin{array}{l}\text { Onafhanklike veranderlikes } \\
\text { Ouderdom van die huishoudelike hoof }\end{array}$ & Aantal jare & $\begin{array}{l}\text { Verskeie studies het aangevoer dat ouderdomsverspreiding onder } \\
\text { huishoudings 'n positiewe invloed op watersekuriteit het (Schleich en } \\
\text { Hillenbrand, 2009; Kenney et al., 2008; Musolesi en Nosvelli, 2007). } \\
\text { Verskeie studies het getoon dat ouer huishoudings in landelike gebiede } \\
\text { van suidelike Afrika meer vatbaar is vir wateronsekerheid, veral diegene } \\
\text { met 'n lae inkomste (Mudau, 2016; Geere et al., 2010; Majuru, 2015). } \\
\text { Ander studies het egter getoon dat ouer huishoudings verstandiger en } \\
\text { wyser is om waterkonflikte en uitdagings in die gemeenskap te hanteer } \\
\text { (Sinyolo, 2013). Die invloed van huishoudelike ouderdom is dus nie voor- } \\
\text { die-hand-liggend nie, en beklemtoon die noodsaaklikheid van meer } \\
\text { studies oor die onderwerp. }\end{array}$ \\
\hline Huishoudelike grootte & Aantal mense in die huishoudelike eenheid & $\begin{array}{l}\text { Verskeie studies het voorgestel dat 'n groter huishoudelike grootte 'n } \\
\text { positiewe druk op huishoudelike watersekuriteit bied as gevolg hoë } \\
\text { aanvraag (Schleich en Hillenbrand, 2009; Hoffmann et al., 2006; Arbues et } \\
\text { al., 2004). Hierdie studies het voorgestel dat groot huishoudelike eenhede } \\
\text { gewoonlik meer water benodig om in hul lewensonderhoud te voorsien } \\
\text { (Dotse, 2016). In 'n vroeëre studie deur Arouna en Dabbert (2010) is } \\
\text { opgemerk dat groter huishoudings arbeidsvoordele kan hê om water uit } \\
\text { gemeenskaplike krane in te samel, veral in landelike gebiede. Dus, met } \\
\text { inagneming van hierdie agtergrond, is meer studies oor verskillende } \\
\text { geografiese gebiede nodig om kennis oor die invloed van huishoudelike } \\
\text { grootte op watersekuriteit te bevorder. }\end{array}$ \\
\hline Waterinfrastruktuur & $\begin{array}{l}\text { Ervaarde probleme met waterinfrastruktuur } \\
\text { (hou van krane) } \\
\text { (1 Ja, } 0 \mathrm{Nee} \text { ) }\end{array}$ & $\begin{array}{l}\text { Waterinfrastruktuur word beskou as een van die belangrikste kwessies } \\
\text { wat die huishoudelike watersekuriteit beïnvloed (Alcamo et al., 2000). } \\
\text { Suid-Afrika het van die beste ingenieursinfrastruktuur om water te } \\
\text { vervoer waar nodig; die infrastruktuur verouder egter mettertyd stadig } \\
\text { en moet heroorweeg word (Colvin et al., 2016). Infrastruktuur hou dus 'n } \\
\text { negatiewe gevolg in vir watersekuriteit op huishoudelike vlak, veral in die } \\
\text { meeste plattelandse gemeenskappe. }\end{array}$ \\
\hline Boer & $\begin{array}{l}\text { Huishoudelike betrokkenheid by Boerdery- } \\
\text { aktiwiteite }\end{array}$ & $\begin{array}{l}\text { Meer water word in die platteland vir boerderydoeleindes verbruik, met } \\
\text { ongeveer } 70 \% \text { varswater wat tydens die voedselproduksieproses vir } \\
\text { besproeiing gebruik word, wat ongeveer } 10 \% \text { vir huishoudelike verbruik } \\
\text { en } 20 \% \text { vir nywerhede laat (Verenigde Nasies, 2012). Ander studies het } \\
\text { voorgestel dat boerdery-aktiwiteite nie noodwendig skoon water benodig } \\
\text { nie (Mzini en Winter, 2015). Op grond van bogenoemde onsekerhede is die } \\
\text { invloed van boerdery op watersekuriteit dus nie voor-die-hand-liggend nie. }\end{array}$ \\
\hline Huwelikstatus & Getroud of andersins & $\begin{array}{l}\text { Huwelikstatus dra ook op die een-of-ander manier by tot die water- } \\
\text { sekuriteit van huishoudings. Daarom sal 'n huishouding onder leiding van } \\
\text { 'n getroude individu waarskynlik toegang hê tot verbeterde waterbronne } \\
\text { as 'n huishouding onder leiding van 'n individu wat nooit getrou het nie } \\
\text { (Irianti et al., 2016). Volgens Iriant et al. (2016), hoe meer huishoudings } \\
\text { immigreer, hoe minder waarskynlik is dit dat hulle waterbeveilig is, en } \\
\text { daarom is getroude huishoudings meer toegewyd en minder geneig } \\
\text { om te migreer. In teenstelling het Adams et al. (2015) 'n studie gedoen } \\
\text { oor faktore wat die watertoegang in Ghana beïnvloed, wat aan die lig } \\
\text { gebring het dat getroude huishoudings minder geneig is om waterbeveilig } \\
\text { te wees as huishoudings wat nooit getrou het nie. Die invloed van die } \\
\text { huishoudelike hoof se huwelikstatus op watersekuriteit op grond van } \\
\text { bogenoemde onsekerhede is dus nie duidelik nie. }\end{array}$ \\
\hline
\end{tabular}


TABEL 1: Veranderlikes wat in die Tobit-model gebruik word (vervolg)

\begin{tabular}{|c|c|c|}
\hline Veranderlikes & Beskrywing & Literatuur \\
\hline Ras van die huisdhuishoudelike hoof & Swart of andersins & $\begin{array}{l}\text { Op die een of ander manier dra ras ook by tot die faktore wat } \\
\text { watersekuriteit vir huishoudings dryf (WaterAid, 2020). Volgens } \\
\text { Hendricks (2003) is dit minder waarskynlik dat swartes toegang het tot } \\
\text { water as blankes. ' } n \text { Studie deur Brooks et al. (2017) het onthul dat wit } \\
\text { huishoudings in die meeste gevalle meer toegang tot water het as swart } \\
\text { huishoudings. Die inkomste-ongelykhede kan dit verklaar omdat blankes } \\
\text { meer inkomste verdien as swartes (Judin, 2019). Op grond van die lae } \\
\text { inkomste in landelike gebiede, het die studie die huishouding se ras om } \\
\text { die watersekuriteit negatief te beïnvloed, veronderstel. }\end{array}$ \\
\hline Diensstatus van die huishoudelike hoof & Werklik of werkloos & $\begin{array}{l}\text { Diensstatus is een van die belangrikste faktore wat die watersekuriteit } \\
\text { beïnvloed. Werkende huishoudelike hoofde verdien inkomste en kan } \\
\text { dit bekostig om waterkoste te betaal in vergelyking met werklose } \\
\text { huishoudelike hoofde (Adams et al., 2015). Daarteenoor verklaar Angoua } \\
\text { et al. (2018) dat die haal van water 'n huishoudelike plig in landelike } \\
\text { gebiede is, en huishoudings met 'n werkende hoof is geneig om hul } \\
\text { huishoudelike pligte om water te haal, te versuim, wat die watersekuriteit } \\
\text { beperk. Daarom is die invloed van die indiensnemingstatus van die } \\
\text { huishouding op watersekuriteit op grond van bogenoemde onsekerhede } \\
\text { nie duidelik nie. }\end{array}$ \\
\hline Onderwysstatus van die huishoudelike hoof & Geen opleiding nie, Primêr, Sekondêr en Tersiêr & $\begin{array}{l}\text { Die opvoedingsvlak van die huishoudelike hoof is een van die belangrikste } \\
\text { faktore wat die watersekuriteit beïnvloed. Adams et al. (2016) het gesê dat } \\
\text { opgeleide huishoudings meer geneig is om waterveilig te wees as diegene } \\
\text { wat nie onderrig het nie. Huishoudelike hoofde met 'n hoë opleiding sal } \\
\text { meer waarskynlik die gevolge van die gebruik van onverbeterde water } \\
\text { begryp en daarom pogings aanwend om die waterkwaliteit daarvan } \\
\text { te verbeter (Adams et al., 2016). Op grond van die bostaande inligting, } \\
\text { het die studie veronderstel dat die onderwysstatus van die hoof van die } \\
\text { huishouding die watersekuriteit positief beïnvloed. }\end{array}$ \\
\hline Huishouding wat water betaal & Water betaal of nie & $\begin{array}{l}\text { Huishoudings wat vir water betaal, is een van die belangrikste faktore } \\
\text { wat die watersekuriteit beïnvloed. Verskeie geleerdes beweer dat } \\
\text { huishoudings wat vir water betaal, gewoonlik veiliger is as diegene wat nie } \\
\text { betaal nie(Pinto et al., 2018; Dlamini, 2015; Kujinga et al., 2014). Volgens } \\
\text { die Wêreldbank (1993), wissel die bereidwilligheid om vir water te betaal } \\
\text { in landelike gebiede van ontwikkelende provinsies tussen inkomste en die } \\
\text { bestaande voorsieningskenmerke. Op grond van die bostaande inligting } \\
\text { is die invloed van die betaling van water op die watersekuriteit dus nie } \\
\text { duidelik nie. }\end{array}$ \\
\hline Toilet wat in die huishouding gebruik word & Gebruik'n puttoilet of spoeltoilet & $\begin{array}{l}\text { Die tipe toilet wat deur 'n huishouding gebruik word, dra ook op die een } \\
\text { of ander manier tot watersekuriteit by. 'n Huishouding wat 'n spoeltoilet } \\
\text { besit, gebruik meer water as diegene wat puttoilette gebruik, wat hul } \\
\text { wateronsekerheid verhoog (Zaied, 2018). Daarteenoor het die SFIAST } \\
\text { (2019) aangevoer dat daar tans dubbele spoeltoilette is wat water } \\
\text { bespaar, wat die hoeveelheid water wat gebruik word om te spoel } \\
\text { verminder. Teen hierdie agtergrondinligting is die invloed van spoeltoilette } \\
\text { op die watersekuriteit dus nie duidelik nie. }\end{array}$ \\
\hline Tyd spandeer om water in te samel & Die werklike tyd om ure in te samel & $\begin{array}{l}\text { Die tyd wat besteë word deur huishoudelike lede om water in te samel, } \\
\text { beïnvloed die watersekuriteit op die een of ander manier. Huishoudings } \\
\text { wat meer tyd spandeer aan die versameling van water, is meer veilig as } \\
\text { diegene wat dit nie doen nie (Lewis, 2016). In landelike gebiede is water in } \\
\text { krane onbetroubaar en moet dit deur huishoudings van ver gehaal word } \\
\text { (Tussupoca, 2016). Op grond van bogenoemde inligting, is die hipotese } \\
\text { dat die tyd wat spandeer word om water deur huishoudings te versamel, } \\
\text { die watersekuriteit negatief beïnvloed. }\end{array}$ \\
\hline
\end{tabular}




\section{Resultate en bespreking}

\section{Sosio-ekonomiese- en demografiese eienskap- pe van die huishoudings wat in die steekproef opgeneem is}

Tabel 2 hieronder bied beskrywende statistieke aan van die 283 huishoudings wat ondervra is in die studie. In verhouding tot die sosio-ekonomiese eienskappe van die respondente, was die huishoudelike hoof se gemiddelde ouderdom 59 jaar, wat in beide gemeenskappe gewissel het van 25 tot 96 jaar oud. In albei gemeenskappe het vroue in geslagskategorie gedomineer, soos aangedui deur $74,6 \%$ vroue in Hamburg en $66,7 \%$ in Melani. Die meerderheid van die Hamburgse huishoudings was getroud (61,3\%), terwyl slegs 45,4\% van die huishoudings in Melani getroud was en in huishoudings woon waarvan die gemiddelde grootte vier lede is. Die meerderheid van die huishoudings wat in die steekproef opgeneem is in Hamburg (43\%) en het aangedui dat hul huishoudelike hoof sekondêre opleiding gehad het, terwyl die meeste huishoudings in Melani aangedui het dat hul huishoudelike hoof primêre onderrig $(44,7 \%)$ gehad het.

Die meerderheid van die huishoudings wat in die gemeenskappe in die steekproef opgeneem is, het aangedui dat hulle meestal afhanklik is van maatskaplike toelaes as hul inkomste, te wete: Hamburg $(76,8 \%)$ en Melani $(84,4 \%)$. Alhoewel die respondente in Melani gesê het dat daar geen afhanklikheid van die landbou as ' $\mathrm{n}$ bron van inkomste is nie, het sommige respondente in Hamburg wel aangedui dat hulle die landbou as ' $n$ bron van inkomste gebruik $(1,4 \%)$. In albei gemeenskappe het die respondente hoë werkloosheidsvlakke aangedui: Hamburg (88\%) en Melani $(90,8 \%)$.

\section{Watersekerheidstatus}

Tabel 3 hieronder toon die Waterarmoede-indeks wat bereken is vir die twee gemeenskappe in die studiegebied, naamlik Hamburg- en Melani-gemeenskappe. Die resultate wys daarop dat die beskikbaarheid van water in die Hamburg-gemeenskap maar min is $(17 \%)$; . Meer mense het egter toegang tot skoon en veilige drinkwater (86\%), en daar word minder tyd geneem om water in te samel $(28 \%)$. Resultate dui verder op 'n waterarmoede-indeks van 16, wat 'n hoër mate van waterstres impliseer. Hierdie bevindings dui op hoë wateronsekerheid, hoofsaaklik as gevolg van verminderde waterbeskikbaarheid. Daarom moet die beskikbaarheid van water vir die Hamburggemeenskap prioriteit geniet om die Waterarmoedeindeks, wat tans baie laag is, te verhoog. Die resultate vir dieMelani-gemeenskap dui ook op lae waterbeskikbaarheid (24\%), hoewel dit effens hoër is as die Hamburggemeenskap, met meer mense met toegang tot skoon drinkwater $(74 \%)$ en daar word meer tyd geneem om water in te samel (33\%). Resultate dui ook op 'n waterarmoedeindeks van 15,7 , wat ' $n$ hoër mate van waterstres impliseer. Hierdie bevindings dui op hoë wateronsekerheid, hoofsaaklik as gevolg van verminderde beskikbaarheid van water en meer tyd om water in te samel. Die prioriteit vir die Melani-gemeenskap moet dus wees om die beskikbaarheid van water en die verminderde tyd wat aan waterversameling bestee word, aan te spreek. Tot dusver het albei gemeenskappe probleme met waterarmoede, hoofsaaklik as gevolg van verminderde beskikbaarheid van water en meer tyd wat aan waterinsameling bestee word, veral vir die Melani-gemeenskap. Dit is egter interessant om te let dat 'n groter aantal mense uit die twee gemeenskappe (Melani: 74\% - Hamburg: 86\%), hoewel hul

TABEL 2: Beskrywende statistieke van huishoudings in die steekproef

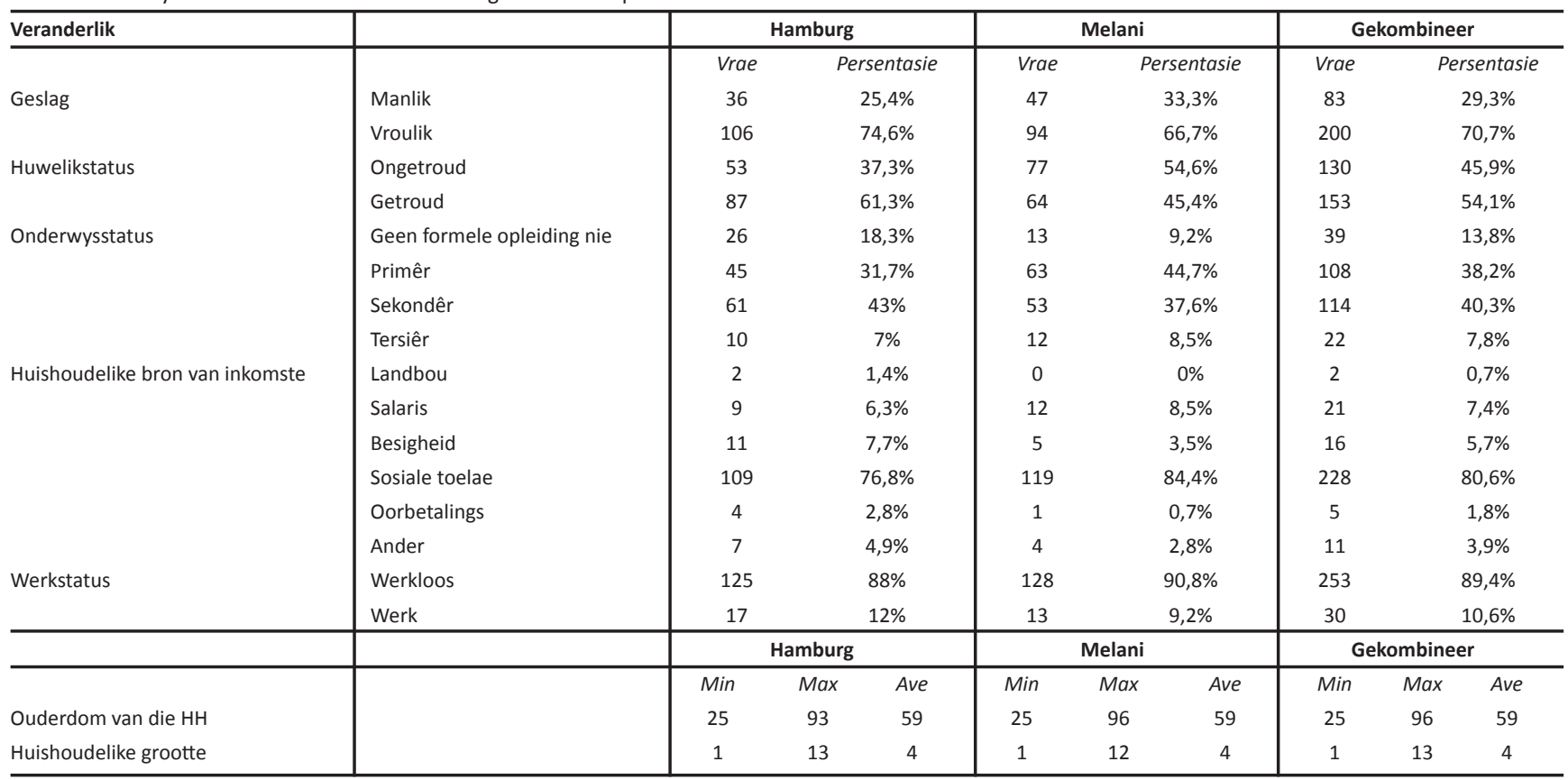


status vir waterbeskikbaarheid baie laag is, die min water waartoe hulle toegang het beskou as oor die algemeen skoon en veilig om te drink. Daarom is die uitdaging aan waterarmoede vir die twee gemeenskappe meer van 'n tegniese en institusionele aard (beskikbaarheid van water en die nabyheid van water vir inwoners). Assefa et al. (2018) het gekyk na waterstres vir huishoudings wat die Waterarmoede-indeks gebruik. Hul resultate het getoon dat 'n gebrek aan institusionele kapasiteit, swak waterinfrastruktuur en onbetroubare kragvoorsiening die hoofoorsake van swak huishoudelike watersekuriteit is. Soortgelyke resultate is ook vroeër waargeneem deur Ogwang en Cho (2014), wat aangedui het dat hulpbronne soos dalende waterbeskikbaarheid per capita, blootstelling aan bottelnekke, kapasiteit en watergebruik van die belangrikste kwessies is wat bydra tot waterarmoede. Die waterarmoede-uitdaging vir die twee gemeenskappe is meer van ' $n$ tegniese en institusionele aard (beskikbaarheid van water en die nabyheid van water vir inwoners).

\section{Ekonometrie-resultate}

\section{Bepalers van watersekuriteitsstatus van huishoudings in die studiegebied}

Tabel 4 gee die resultate van die faktore wat die watersekuriteitstatus in die studiegebied beïnvloed, wat geskat is met behulp van ' $n$ Tobit-regressiemodel. Die Waterarmoede-indeks is gebruik as die afhanklike veranderlike op die Tobit-regressiemodel. Tobit-regressie is gebruik omdat dit wenslike eienskappe het om konsekwente maksimum waarskynlikheidsramings te lewer en om die aard van die ingekorte afhanklike veranderlike te akkom- modeer. Die variansie-inflasie-faktor (VIF) is gebruik om die erns van multi-kollineariteit tussen die onafhanklike veranderlikes te toets, en die gevolglike waardes was minder as 10 . Uit die resultate kan afgelei word dat multikollineariteit nie ' $n$ probleem was nie, aangesien alle VIFwaardes onder 10 is. Die resultate toon ook dat die chikwadraat ( $p$-waarde $=0,0001$ ) hoog en statisties beduidend was vir 'n log-waarskynlikheidsverhouding en Pseudo R2 van 0,368 .

Vir die Tobit-regressiemodel dui die teken van die koëffisiënt die rigting aan van die invloed wat die onafhanklike veranderlike op die afhanklike veranderlike uitoefen. Dus, 'n positiewe waarde toon aan dat ' $n$ toename in die veranderlike die watersekuriteit van huishoudings verhoog, as ander veranderlikes konstant bly. 'n Negatiewe waarde impliseer dat ' $n$ toename in die veranderlike die watersekuriteit van die huishouding verminder, as ander veranderlikes konstant bly.

Die resultate dui aan dat faktore soos die betaling van water, die tipe toilet wat gebruik word en die tyd wat spandeer word om water in te samel, die waterveiligheidstatus van die huishouding in die studiegebied beïnvloed. Tyd om water te versamel was beduidend op $1 \%$ as daar vir water betaal is. Die tipe toilet wat gebruik is, was betekenisvol op $5 \%$. Nege van die 12 onafhanklike veranderlikes wat in die model gebruik is, was onbeduidend: ouderdom, huishoudelike grootte, huwelikstatus, boerderystatus, inkomstebron, onderwys, waterinfrastruktuur en ras. Een van die drie beduidende onafhanklike veranderlikes het 'n negatiewe teken gehad, naamlik tyd

TABEL 3: Waterarmoede-indeks vir Melani- en Hamburg-gemeenskappe

\begin{tabular}{l|c|c|c}
\hline Gemeenskap & Waterbeskikbaarheid (\%) & $\begin{array}{c}\text { Toegang tot skoon en veilige } \\
\text { drinkwater (\%) }\end{array}$ & $\begin{array}{c}\text { Indeks van tyd spandeer aan } \\
\text { waterversameling }\end{array}$ \\
\hline Gewigte & 0.5 & 0,25 & 0,25 \\
Melani gemeenskap & 24 & 74 & 33 \\
Hamburg-gemeenskap & 17 & 86 & 28 \\
\hline
\end{tabular}

Bron: Veldopname, 2019

TABEL 4: Bepalers van watersekuriteitsstatus: Tobit-regressiemodelresultate

\begin{tabular}{|c|c|c|c|}
\hline Veranderlikes & Geskatte ko-eff & Std. Fouteer & b/ betekenisvlak \\
\hline Ouderdom van die huishoudelike hoof & 0.00008 & 0,0123 & 0,994 \\
\hline Huweliks & 0.3890 & 0.312 & 0.215 \\
\hline Huishoudelike grootte & $-0,0851$ & 0,066 & 0.199 \\
\hline Water betaal & 0.7767 & 0,371 & $0,038 * *$ \\
\hline Werkstatus & $-0,6819$ & 0.737 & 0,356 \\
\hline Ras van die huishoudelike hoof & -2.9296 & 1.674 & 0,081 \\
\hline Soort toilet gebruik & 1.2644 & 0,624 & $0,044 * *$ \\
\hline Waterinfrastruktuur & 0.5168 & 0.309 & 0,096 \\
\hline Boer & 0.3846 & 0,308 & 0.214 \\
\hline Tyd spandeer & -0.5081 & 0.114 & $0,000 * * *$ \\
\hline \multicolumn{4}{|l|}{ Onderwys } \\
\hline Primêr & 0,1577 & 0.463 & 0.734 \\
\hline Sekondêr & 0.6709 & 0,357 & 0,062 \\
\hline Tersiêr & 0.2659 & 0,639 & 0.678 \\
\hline Konstante & 13.4737 & 0,891 & $0,000 * * *$ \\
\hline
\end{tabular}

Opmerking ${ }^{* * *}$ en ${ }^{* *}$ toon die vlak van betekenisvolheid op onderskeidelik $1 \%$ en $5 \%$ vlakke. 
spandeer om water in te samel. Die negatiewe teken dui aan dat ' $n$ toename in die voorspellingsveranderlike gepaard gaan met ' $n$ afname in die huishouding se watersekuriteit, wat wateronsekerheid verhoog. Twee voorspellingsveranderlikes, naamlik die tipe toilet wat gebruik word en die betaling vir water. het ' $n$ positiewe teken wat aandui dat ' $n$ verbetering in hierdie onafhanklike veranderlikes geassosieer word met ' $n$ toename in die watersekuriteit van huishoudings. As gevolg hiervan sal dit wateronsekerheid verlaag.

Die betaling vir water was beduidend (p-waarde: 0,038) en het ' $n$ positiewe korrelasie getoon met die WPI. Die resultate dui aan dat 'n eenheidsverandering in ' $n$ huishouding se bereidwilligheid om vir water te betaal, gepaard gaan met 'n afname van 0,7767 eenhede aan huishoudelike watersekuriteit, as alle ander onafhanklike veranderlikes konstant gehou word. Die resultate impliseer dat huishoudings met die vermoë om vir water te betaal, minder kanse het dat water kan opraak. Dit kan wees omdat huishoudings met die vermoë om vir water te betaal, toegang tot verskillende bronne van gekoopte water het; daarom is hulle waterveilig in vergelyking met huishoudings met ' $n$ beperkte vermoë om water te betaal. Omdat water noodsaaklike ekonomiese goedere is waarvoor verbruikers moet betaal, beweer verskeie geleerdes dat huishoudings bereid is om vir water te betaal om sodoende die watersekuriteit te verhoog in terme van betroubaarheid en goeie kwaliteit water (Pinto et al., 2018; Dlamini, 2015; Kujinga et al., 2014). Mezgebo en Ewnetu (2015) getuig dat die meeste huishoudings bereid is om vir water te betaal om watertoevoer te verbeter. Mezgebo en Ewnetu (2015) brei verder uit dat huishoudings met 'n beter inkomste, 'n kort afstand na die waterbron, en 'n hoë onderwysvlak het, meestal verband hou met huishoudings wat bereid is om te betaal vir verbeterde watervoorsiening.

Die tipe toilet wat die huishouding gebruik, was beduidend ( $p$-waarde $<0,05$ ) en het ' $n$ positiewe verhouding met die WPI gehad. Die resultate dui aan dat 'n positiewe eenheidsverandering in die tipe toilet wat in die huishouding gebruik word (van die gebruik van die buitetoilet na die gebruik van die spoeltoilet) geassosieer word met 'n toename van 1.264 eenhede se huishoudelike watersekuriteit, as alle ander onafhanklike veranderlikes konstant gehou word. Dit impliseer dat as meer huishoudings spoeltoilette gebruik as buite-toilette, daar 'n groter kans is dat hul watersekuriteitstatus verhoog sal word. Dit kan wees omdat huishoudings met spoeltoilette toegang het tot skoon water om te spoel en toegang het tot skoon sanitasie. Die Switserse Federale Instituut vir Waterwetenskap en Tegnologie (SFIAST) (2019) dui aan dat daar tans dubbele spoel waterbesparende toilette is wat die water wat gebruik word om te spoel, verminder. Die toegang tot ' $\mathrm{n}$ spoeltoilet verminder dus nie noodwendig die watersekuriteit van huishoudings nie. Die bevindings word ook ondersteun in UNEP (2002), wat beweer dat dubbele spoel waterbesparende toilette bestaan en verskillende spoelvolumes gebruik om watergebruik te verminder, en dat sekere ander toilette die urine afsonderlik gebruik en hergebruik om te spoel en water te bespaar, wat watersekuriteit verhoog. (UNESCO-IHE, 2009). Larsen et al. (2001) getuig dat die bronskeiding uriene toilette verskeie voordele het en ongeveer $80 \%$ bespaar van die water wat gebruik word om die toilette te spoel. Om dus spoeltoieltte te hê, dui nie noodwendig daarop dat die huishouding watersekuriteit sal hê nie en verminder nie watersekuriteit nie.

Die tyd wat die huishouding bestee het om water te versamel, het ' $n$ beduidende ( $p$-waarde $<0,1$ ) en negatiewe verband met die WPI gehad. ' $n$ Toename in die eenheid wat die tyd aandui wat die huishouding spandeer om water in te samel, hou verband met 'n afname van 0,5081 eenhede aan huishoudelike watersekuriteit, as alle ander onafhanklike veranderlikes konstant bly. Die resultate dui aan dat hoe meer tyd deur huishoudings bestee word om water in te versamel, meer geneig om wateronseker te wees. In die studiegebied is water in die krane van die gemeenskap gewoonlik gedurende ' $n$ jaar vir lang tydperke nie beskikbaar nie, wat die huishoudings dwing om lang afstande te loop na riviere, damme en boorgate in die gemeenskap op soek na water. Tyd om water in te samel, dwing huishoudings om hul waterverbruik te verminder as ' $\mathrm{n}$ besparingsmeganisme wat hul watersekuriteit negatief in gevaar stel. In 'n vergelykbare vorige studie deur Tussupova (2016) is opgemerk dat huishoudings in landelike gebiede openbare waterbronne gebruik en lang afstande moet stap en baie tyd gebruik om water in te samel om hul watersekuriteitsstatus te verbeter. Soortgelyke resultate is waargeneem deur Lewis (2016), wat beweer het dat die meeste plattelandse huishoudings meeste dae kilometers moet aflê om in hul daaglikse waterbehoeftes te voorsien, veral gedurende droë seisoene. Die tyd wat geneem word om water in landelike gebiede in te samel, het ' $n$ negatiewe uitwerking op die armes en word in die meeste gevalle 'n wesenlike versperring vir volhoubare ontwikkeling en huishoudelike watersekuriteit (Greere en Cortobius, 2017). Daarom verminder die tyd wat gebruik word om water deur arm huishoudings in landelike gebiede te gaan haal, die tyd om lewensonderhoud te genereer, soos om werk te kry, wat die armoede vir hierdie huishoudings verhoog (Greere en Cortobius, 2017).

\section{Afsluiting}

Hierdie studie is ontwerp om huishoudelike watersekuriteitsdeterminante in Hamburg-kus- en Melanibinnelandse gebiede in die Oos-Kaap Provinsie van SuidAfrika, te ondersoek. Data is geanaliseer met behulp van beskrywende statistiek, die Waterarmoede-indeks en die Tobit-regressiemodel. Die studie het tot die gevolgtrekking gekom dat wateronsekerheid in die studiegebied 'n ernstige probleem is, hoofsaaklik as gevolg van die onbeskikbaarheid van waterbronne en die tyd wat geneem is om water in te samel. Die artikel kom tot die gevolgtrekking dat die fokus op wateronsekerheid in die studiegebiede meer op 
strategieë moet wees om die huishouding se tyd om water in te samel, te verminder. Die studie kom verder tot die gevolgtrekking dat sekere faktore die huishoudelike watersekuriteit positief beïnvloed (die tipe toilet wat gebruik word en om vir water te betaal), terwyl ander faktore die huishoudelike watersekuriteit negatief beïnvloed (tyd om water in te samel). Om die watersekuriteit in die studiegebiede te verbeter, is dit nodig om die waterinfrastruktuur vir watervoorsiening en die tipe toilette te verbeter. Die voorsiening van waterinfrastruktuur sal ook die tyd wat spandeer word om water te versamel, verbeter.

\section{Aanbevelings}

Op grond van die inligting verkry uit die studie beveel die artikel aan om die vlak van watersekuriteit in die studiegebied en soortgelyke gebiede te verhoog, behoort daar aandag gegee te word aan die verbetering van waterinfrastruktuur vir watervoorsiening en aandag behoort geskenk te word aan die tipe toilette wat gebruik word. Die voorsiening van waterinfrastruktuur sal ook die tyd wat spandeer word om water in te samel, verbeter. Dit is ook nodig om te verseker dat water teen bekostigbare pryse beskikbaar is in betalende gemeenskappe en dat huishoudings daarmee saam hul waterrekeninge kan betaal. Die regering moet ook toesien dat huishoudings op die platteland toegang het tot spoeltoilette wat nie met water werk nie, wat hul watersekuriteit sal verbeter. Laastens beveel die studie aan om meer moeite te doen om seker te maak dat skoon, beskikbare kraanwater nader aan huishoudings gevestig word om die tyd wat spandeer word om water in te samel, te verminder.

\section{Erkennings}

Hierdie studie was deel van 'n groot projek wat uitgevoer is deur African Climate Development Initiative (ACDI), Universiteit van Kaapstad (UCT), in samewerking met die Universiteit van Fort Hare (UFH) en die Universiteit van KwaZulu-Natal (UKZN). Die projek is gefinansier deur die Waternavorsingskommissie (WRC) (K5 / 2718) met die titel, "' die ondersoek na die bewyse van 'n verband tussen water-energie-voedsel-verband met volhoubare plaaslike lewensbestaan en welstand in Suid-Afrika. "

\section{Openbaarmakingsverklaring}

Geen potensiële belangebotsings is deur die outeurs gerapporteer nie.

\section{Befondsing}

Die werk is befonds deur die Risk and Vulnerability Science Centre (RSVC) en Water Research Commission (WRC) (K5 / 2718).

\section{Aantekeninge oor bydraers}

Mnr Thulani Ningi is gebore in Keiskammahoek (Qoboqobo) in die Oos-Kaap Provinsie, Suid-Afrika. Hy het Phakamisani Senior Secondary School in Keiskammahoek bygewoon. In 2016 behaal hy sy eerste graad in Landbou: Landbou-ekonomie aan die Universiteit van Fort Hare. In 2017 behaal hy sy Honneursgraad in Landbou: Landbou-ekonomie. Thulani studeer tans vir ' $n$ meestersgraad met as belangstellingsveld die verband tussen water en energie op huishoudelike vlak. Hy het gewerk aan 'n gesamentlike projek tussen die Universiteit van Fort Hare (RSVC), die Universiteit van Kaapstad (ACDI) en die Universiteit van KwaZulu-Natal.

Prof Amon Taruvinga is in Zimbabwe gebore. Hy behaal sy BSc (Hons)-graad in Landbou-ekonomie aan die Universiteit van Zimbabwe en sy $\mathrm{PhD}$, ook in Landbouekonomie, aan die Universiteit van Fort Hare, Suid-Afrika (2012). Hy is tans medeprofessor in die Departement Landbou-ekonomie en -voorligting aan die Universiteit van Fort Hare, Suid-Afrika, en 'n CIRCLE Visiting Fellow (CVF). Hy is ook die platformvoorsitter vir Suider-Afrika se klimaatverandering- en biodiversiteitsnavorsingsplatform (SACC \& BRP). Dr Taruvinga spesialiseer in biodiversiteit, omgewingsekonomie, interaksies met natuurlewe, voedselsekerheid en klimaatsverandering en kleinboerdery. Hy is geïnteresseerd in die bevordering van die volhoubare interaksie tussen mens en natuur.

Dr Leocadia Zhou is die direkteur vir die Wetenskaplike Sentrum vir Risiko's en Kwesbaarheid (RVSC) wat in die Fakulteit Natuurwetenskappe en Landbou aan die Universiteit van Fort Hare aangebied word. Haar sterkpunt lê in ' $n$ multidissiplinêre benadering en verhouding met regeringsamptenare op provinsiale en nasionale vlak, en sy was baie betrokke by die oorbrugging van die gaping tussen wetenskap en beleidskoppelvlak.

Dr Saul Ngaravais 'n post-doktorale genoot in die Wetenskaplike Sentrum vir Risiko's en Kwesbaarheid, Universiteit van Fort Hare, Suid-Afrika, met 'n PhD in Landbouekonomie (Universiteit van Fort Hare, Suid-Afrika) (2019), MSc Landbou-ekonomie (Universiteit van Fort Hare, SuidAfrika) (2016), Magister in Bedryfsadministrasie (Nasionale Universiteit vir Wetenskap en Tegnologie, Zimbabwe) (2015) en BSc Honneurs (Universiteit van Zimbabwe, Zimbabwe) (2010). Dr. Ngarava het 20 tydskrifpublikasies, een boekhoofstuk en twee tegniese verslae opgestel. Navorsingsbelangstellings: Landbou-ekonomie, Hulpbronekonomie, Landelike ontwikkeling, Voedsel-waterenergie-sekuriteit, Klimaatsverandering, Natuurlike hulpbronbestuur, Geslagsstroom, Navorsing en ontwikkeling

\section{ORSID}
T. Ningi
A. Taruvinga
L. Zhou
https:/ / orcid.org/0000-0001-9491-4695
S. Ngarava https:/ / orcid.org/0000-0002-0344-4710 https:/ / orcid.org/0000-0002-8462-0287 


\section{Verwysings}

Adams, E.A., Boateng, G.O., and Amoyaw, J.A., 2016. Socioeconomic and demographic predictors of potable water and sanitation access in Ghana. demographic predictors of potable water and
Social Indicators Research, 126(2), p. 673-687.

Africa, S. 2012. Final Project Report for 2011 START Grants for Global Change Research in Africa the Impact of Climate Change on Food Security among Coastal Communities of Keiskamma, in the Eastern Cape, South Africa.

Ahmad, I. and Sattar, A., 2010. Factors determining public demand for safe drinking water (A Case Study of District Peshawar). PIDE Working Paper 2010 (58). Islamabad, Pakistan: Pakistan Institute of Development Economics.

Akinyemi, B.E., Mushunje, A. and Fashogbon, A.E., 2018. Factors explaining household payment for potable water in South Africa. Cogent Social Sciences, 4(1), p.1464379.

Alcamo, J., Henrichs, T. And Rösch, T., 2000. World water in 2025: Global modelling and scenario analysis for the world commission on water for the 21st century, World water Series Report 2, Centre for Environmental Systems Research, University of Kassel, Germany.

Angoua, E.L.E., Dongo, K., Templeton, M.R., Zinsstag, J. and Bonfoh, B., 2018 Barriers to access improved water and sanitation in poor peri-urban settlements of Abidjan, Côte d'Ivoire. PloS one, 13(8), p. 0202928

Arbúes, F., Barberan, R. and Villanua, I., 2004. Price impact on urban residential water demand: A dynamic panel data approach. Water Resources Research, 40(11).

Arouna, A. and Dabbert, S., 2010. Determinants of domestic water use by rural households without access to private improved water sources in Benin: A seemingly unrelated Tobit approach. Water Resources Management, 24(7), p. seemingly unre.

Assefa, Y., Babel, M., Sušnik, J. and Shinde, V., 2019. Development of a Generic Domestic Water Security Index, and Its Application in Addis Ababa, Ethiopia. Water, 11(1), p. 37.

Brocklesby, M.A. and Fisher, E., 2003. Community development in sustainable livelihoods approaches: an introduction. Community Development Journal, 38(3), p. $185-198$

Brooks, C.J., Gortmaker, S.L., Long, M.W., Cradock, AL and Kenney, E.L., 2017. Racial/ethnic and socioeconomic disparities in hydration status among U.S adults and the role of tap water and other beverage intake. American journal of public health, 107(9), p. 1387-1394.

Carney, D., 1999. Livelihood approaches compared: a brief comparison of the livelihoods approaches of the UK Department for International Development (DFID), CARE, Oxfam and the UNDP. A brief review of the fundamental (DFID), CARE, Oxfam and the UNDP. A brief review of the fundamental
principles behind the sustainable livelihood approach of donor agencies. principles behind the sustainat
Livelihoods connect. London.

Chambers, R. and Conway, G., 1991. Sustainable rural livelihoods: practical concepts for the 21st century. Discussion paper 296. Institute of Development Studies, Univeristy of Sussex, Brighton, UK.

Colvin, C., Muruven, D., Lindley, D., Gordon, H. And Schachtschneider, K., 2016. Water Facts and Futures: Rethinking South 'Africa's water future, WWF-SA Water Facts and Futures, p. 2-96.

Cook, C. and Bakker, K., 2012. Water security: Debating an emerging paradigm Global environmental change, 22(1), p. 94-102.

Department of Water Affairs. 2004, Strategic Framework for water services, water is life, sanitation is dignity, South Africa.

Dlamini, N., 2015. Households' Water Use Demand and Willingness to Pay for Improved Water Services: A Case Study of Semi-Urban Areas in the Lubombo and Lowveld Regions of Swaziland. Masters dissertation, Lilongwe University of Agriculture and Natural Resources (LUANR), Swaziland.

Donohue, C. and Biggs, E., 2015. Monitoring socio-environmental change for sustainable development: Developing a Multidimensional Livelihoods Index (MLI). Applied Geography, 62, p. 391-403.

Dotse, L.N.A., 2016. Exploring the relationship between water scarcity on food and nutritional security in rural households in the Nageleni location, Eastern Cape. Masters Dissertation, University of Witwatersrand, South Africa.

Geere, J.A. and Cortobius, M., 2017. Who carries the weight of water? Fetching water in rural and urban areas and the implications for water security. Water Alternatives, 10(2), p. 513-540.

Geere, J.A.L., Hunter, P.R. And Jagals, P., 2010. Domestic water carrying and its implications for health: a review and mixed methods pilot study in Limpopo Province, South Africa. Environmental Health, 9(1), p. 52.

Government of Canada, 2017. Water in developing countries. Government of Canada report 2017. Document available online; https://www.international.gc.ca/ world-monde/issues_development-enjeux_developpement/environmental protection-protection environnement/water-eau.aspx?lang=eng [Accessē 30 May 2020].

Grecksch, K., 2015. Adaptive capacity and water governance in the Keiskamma River catchment, Eastern Cape Province, South Africa. Water SA, 41(3), p. 359River
368.
Hardberger, A., 2005. Life, liberty, and the pursuit of water: evaluating water as a human right and the duties and obligations it creates. Northwestern University Journal of International Human Rights, 4, p.331.

Heijnen, M., Cumming, O., Peletz, R., Chan, G.K.S., Brown, J., Baker, K. and Clasen, T., 2014. Shared sanitation versus individual household latrines: A systematic review of health outcomes. PloS one, 9(4).

Hendricks, F., 2003. Fault-lines in South African democracy: continuing crises of inequality and injustice. Nordic Africa Institute, (22).

Hinojosa, L., Villegas, W.G. and Muñoz, P.A., 2018. Exploring water security and water demand determinants in rural areas. The case of canton Cotacachi in Ecuador. Water resources and rural development, 10, p. 22-32.

Hoffmann, M., Worthington, A. And Higgs, H., 2006. Urban water demand with fixed volumetric charging in a large municipality: the case of Brisbane, Australia. Australian Journal of Agricultural and Resource Economics, 50(3), p. 347-359.

Holmatov, B., Lautze, J., Manthrithilake, H. and Makin, I., 2017. Water security for productive economies: Applying an assessment framework in southern Africa. Physics and Chemistry of the Earth, Parts A/B/C, 100, p. 258-269.

Hope, R., Thomson, P., Koehler, J. and Foster, T., 2020. Rethinking the economics of rural water in Africa. Oxford Review of Economic Policy, 36(1), p .171-190.

Irianti, S., Prasetyoputra, P. and Sasimartoyo, T.P., 2016. Determinants of household drinking-water source in Indonesia: An analysis of the 2007 Indonesian family life survey. Cogent Medicine, 3(1), p. 1151143.

Israel, G.D., 2013. Determining sample size peod6, Agricultural Education and Communication Departemnt, Florida Cooperative Extension Service, Institute of Food and Agricultural Science, University of Florida, Gainesville.

Jacob, B., 2018. Regular, lengthy water cuts hit residents hard. Document available online: https://www.dispatchlive.co.za/news/2018-11-03-regular-lengthywater-cuts-hit-residents-hard/ [Accessed 6 November 2018].

Januar, R., 2018. Toward Sustainable Consumption: Model-Based Policy Analysis on Household Food, Energy, and Water Consumption in the Netherlands.

Jensen, O. and $\mathrm{Wu}, \mathrm{H} ., 2$ 2018. Urban water security indicators: Development and pilot. Environmental Science \& Policy, 83, p. 33-45.

Judin, J., 2019. Analysis of inequality in South Africa remains shallow. Document available online: https://mg.co.za/article/2019-12-01-00-analysis-ofinequality-in-south-africa-remains-shallow/ [Accessed 28 July 2020].

Jury, WA and Vaux, H., 2005. The role of science in solving the world's emerging water problems. Proceedings of the National Academy of Sciences, 102(44), p. $15715-15720$.

Kenney, D.S., Goemans, C., Klein, R., Lowrey, J. And Reidy, K., 2008. Residential water demand management: lessons from Aurora, Colorado. JAWRA. Journal of the American Water Resources Association, 44(1), p. 192-207.

Kujinga, K., Vanderpost, C., Mmopelwa, G. And Wolski, P., 2014. An analysis of factors contributing to household water security problems and threats in different settlement categories of Ngamiland, Botswana. Physics and in different settlement categories of
Chemistry of the Earth, 67, p. 187-201.

Larsen, T.A., Peters, I., Alder, A., Eggen, R., Maurer, M. and Muncke, J., 2001. Peer reviewed: re-engineering the toilet for sustainable wastewater management.

Lewis, L., 2016. Rural and urban water issues in Africa. The Water Project. Document available online: https://thewaterproject.org/water-crisis/waterin-crisis-rural-urban-africa [Accessed 20 June 2020].

Mabhaudhi, T., Mpandeli, S., Nhamo, L., Chimonyo, V.G., Nhemachena, C., Senzanje, A., Naidoo, D. and Modi, A.T., 2018. Prospects for improving irrigated agriculture in southern Africa: Linking water, energy and food. Water, 10(12), p. 1881.

Majuru, B., 2015. Unreliable water supplies and household coping strategies in periurban South Africa. Doctoral dissertation, University of East Anglia, Norwich.

Martens, B., 2015. Livelihoods and Climate Change in Hamburg: Issues for Food Security. Masters dissertation, Rhodes University, South Africa.

Maziya, M., Mudhara, M. And Chitja, J., 2017. What factors determine household food security among smallholder farmers? Insights from Msinga, KwaZuluNatal, South Africa. Agrekon, 56(1), p. 40-52.

McGarvey, S.T., Buszin, J., Reed, H., Smith, D.C., Rahman, Z., Andrzejewski, C., Awusabo-Asare, K. and White, M.J., 2008. Community and household determinants of water quality in coastal Ghana. Journal of water and health, 6(3), p. 339-349.

Meissner, R., Funke, N., Nortje, K., Jacobs-Mata, I., Moyo, E., Steyn, M., Shadung, J., Masangane, W. and Nohayi, N., 2018. Water security at local government leve in South Africa: a qualitative interview-based analysis. The Lancet Planetary in South Africa:
Health, 2, p. S17.

Mezgebo, G.K. and Ewnetu, Z., 2015. Households willingness to pay for improved water services in urban areas: A case study from Nebelet town, Ethiopia. Journal of Development and Agricultural Economics, 7(1), p. 12-19. 
Mhangara, P., Kakembo, V., And Lim, K., 2011. Soil erosion risk assessment of the Keiskamma catchment, South Africa using G.I.S. and remote sensing. Environmental Earth Sciences, 65(7), p. 2087-2102.

Mothetha, M., Nkuna, Z. and Mema, V., 2013. The challenges of rural water supply: a case study of rural areas in Limpopo Province. Paper presented at the 3rd Southern regional YWP conference, 16-18 July, Stellenbosch, Western Cape, South Africa.

Mudau, L.S., 2016. Domestic safe water management in poor and rural households. Doctoral dissertation, Tshwane University of Technology, South Africa.

Musolesi, A. And Nosvelli, M., 2007. Dynamics of residential water consumption in a panel of Italian municipalities. Applied Economics Letters, 14(6), p. 441-444.

Mzini, L.L. And Winter, K., 2015. Analysis of grey-water used for irrigating vegetables and possible effects on soils in the vicinity of Umtata Dam, Eastern Cape. Water S.A., 41(1), p. 115-120.

Ngarava, S., Zhou, L. and Monde, N., 2019. Gendered water insecurity: A structural equation approach for female headed households in south Africa. Water, 11(12), p. 2491.

Ngcobo, L., 2017. Perceptions of rural households about the role and effect of biogas production on rural household income in Raymond Mhlaba Local Municipality. 'Master's Thesis, University of Fort Hare, South Africa.

Nicholas, K., Bentley, M., Terán, E. and Thompson, A., 2019. Water security in the Galápagos: Socioecological determinants and health implications. EcoHealth, p. 1-14.

Njoko, S. and Mudhara, M., 2017. Determinant of 'farmers' ability to pay for improved irrigation water supply in rural KwaZulu-Natal, South Africa. Wate S.A., 43(2), p. 229-237.

Nkonkobe Municipality., 2012. Nkonkobe Municipality-Integrated Development Plan Review Document 2010/2011. Document available online: http://www. nkonkobe.co.za/nkonkobeidp20112012.pdf. [Accessed on 30 May 2018].

Nkuna, Z.W. And Ngorima, E., 2011. Challenges for water service delivery and its impact on South Africa's rural communities: The case of Thambonkulu, the small rural community in South Africa. Paper presented at the 1st YWP conference, December, Kampala

Ogwang, T. And Cho, D.I., 2014. A conceptual framework for constructing a corruption diffusion index. Journal of Business Ethics, 125(1), p. 1-9.

Pinto, F.S., Tchadie, A.M., Neto, S. And Khan, S., 2018. Contributing to water security through water tariffs: some guidelines for implementation mechanisms. Journal of Water, Sanitation and Hygiene for Development, 8(4), p. 730-739.

Reddy, B., 2004. Economic and Social Dimensions Of Household Energy Use: Case Study Of India, Mumbai, India.

Rhodes, B. and McKenzie, T., 2018. To what extent does socioeconomic status still affect household access to water and sanitation services in South Africa? Journal of Economic and Financial Sciences, 11(1), p. 1-9.

Schleich, J. And Hillenbrand, T., 2009. Determinants of residential water demand in Germany. Ecological Economics, 68(6), p. 1756-1769.

Schleich, J. and Hillenbrand, T., 2009. Determinants of residential water demand in Germany. Ecological Economics, 68(6), p. 1756-1769.

Scoones, I., 1998. Sustainable rural livelihoods: A framework for analysis. Working Paper 72, Institute for Development Studies (IDS), Brghton, UK.

Scoones, I., 2009. Livelihoods perspectives and rural development. The Journal of Peasant Studies, 36(1), p. 171-196.

Sershen, S., Rodda, N., Stenström, T.A., Schmidt, S., Dent, M., Bux, F., Hanke, N., Buckley, C.A. and Fennemore, C., 2016. Water security in South Africa: perceptions on public expectations and municipal obligations, governance and water reuse. Water S.A., 42(3), p. 456-465.

Sershen, S., Rodda, N., Stenström, T.A., Schmidt, S., Dent, M., Bux, F., Hanke, N., Buckley, C.A. and Fennemore, C., 2016. Water security in South Africa: perceptions on public expectations and municipal obligations, governance and water re-use. Water SA, 42(3), p. 456-465.

Sharaunga, S. and Mudhara, M., 2016. Factors influencing water-use security among smallholder irrigating farmers in Msinga, KwaZulu-Natal Province. Water Policy, 18(5), p. 1209-1228.

Sinyolo, S., 2013. The impact of smallholder irrigation and water security on household welfare: the case of Tugela Ferry irrigation scheme in KwaZuluNatal, South Africa. Masters dissertation, University of Kwazulu Natal, South Africa.

Sinyolo, S., Mudhara, M. and Wale, E., 2014. Water security and rural household food security: Empirical evidence from the Mzinyathi district in South Africa. Food Security, 6(4), p. 483-499.
Solesbury, W., 2003. Sustainable livelihoods: A case study of the evolution of DFID policy. Overseas Development Institute, Working paper 217, 1-36, London.

Soyapi, C.B., 2017. Water security and the right to water in Southern Africa: An overview. Potchefstroom Electronic Law Journal, 20(1).

Statistics South Africa, 2013. Ngqushwa. Document available online: http://beta2 statssa.gov.za/?page id=993\&id=ngqushwa-municipality [Accessed 30 November 2018]

Statistics South Africa, 2016. Community Survey. Document available online: http://cs2016.statssa.gov.za/wp-content/uploads/2016/07/NT-30-06-2016-
RELEASE-for-CS-2016-_Statistical-releas_1-July-2016.pdf [Accessed 03 December 2019]

Sullivan, C., 2002. Calculating a water poverty index. World Development, 30(7), p. $1195-1210$.

Swiss Federal Institute of Aquatic Science and Technology (SFIAST). 2019. Flush toilets. Document available online: https://sswm.info/sswm-universitycourse/module-6-disaster-situations-planning-and-preparedness/furtherresources/flush-toilets [Accessed 28 June 2019].

Tussupova, K., 2016. Supplying rural Kazakhstan with safe water and sanitation. Doctoral thesis, Lund University,Sweden.

UNESCO-IHE, AND UNEP/GPA, 2009. Compendium of Technologies. United Nations Educational, Scientific and Cultural Organization (UNES), Institute for Water Education (I.H.E.) and United Nations Environment Programme Global Water Education (I.H.E.) and United Nations Environment Programme Global Programme of Action. Document available online: http://www.unesco.org/
new/en/santiago/natural-sciences/hydrological-systems-and-global-change/ new/en/santiago/natural-sciences/hydrological-systems-and-global-changer
unesco-ihe-institute-for-water-education/ [Accessed 29 October 2019].

United Nations (U.N.), 2012. Managing water under uncertainty and risk: Facts and figures from the United Nations World Water Development Repor 4 (WWDR4). Document available online: https://unesdoc.unesco.org/ ark:/48223/pf0000215492 [Accessed 20 October 2018].

UNITED NATIONS ‘CHILDREN'S FUND and WORLD HEALTH ORGANIZATION (UNICEF and WHO), 2015. Progress on Sanitation and Drinking Water: 2015 Update and M.D.G. Assessment. URL: http://www.unicef.org/publications/files/ Progress on Sanitation and Drinking_Water_2015_Update_pdf [Accessed 20 May 2020].

United Nations Environmental Programme (UNEP), 2002. A directory of Environmentally sound technologies for the integrated management of solid, liquid and hazardous waste for small island developing states (SIDS) in the pacific region. Document available online: https://iwlearn.net/ documents/3901 [Accessed 20 May 2019].

UN-Water, 2019. WHO and UNICEF launch updated estimates for water, sanitation and hygiene. Document available online: https://www.unwater.org/whoand-unicef-launch-updated-estimates-for-water-sanitation-and-hygiene/ [Accessed on 30 May 2020]

van der Vyver, C., 2013. Water poverty index calculation: Additive or multiplicative function. Journal of South African Business Research, 2013.

Water-Aid, 2017. The sustainable development goals and WaterAid. Document available online: https://www.wateraid.org/au/ [Accessed on 20 May 2020].

Water-Aid, 2020. All of the freshwater resources we depend on come from the natural environment. But a number of factors can combine to threaten water security, and force the world's poorest communities to drink dirty water Document available online: https://washmatters.wateraid.org/water-security [Accessed 20 June 2020].

World Bank Water Demand Research Team, 1993. The demand for water in rura areas: determinants and policy implications. The World Bank Research Observer, 8(1), p. 47-70.

World Wide Fund South Africa (WWF-SA), 2017. Scenarios for the future of water in South Africa. Cape Town, South Africa.

World Wide Fund, 2012. Water in Africa. World Wide Fund for Nature. Document available online: https://www.ascleiden.nl/content/webdossiers/water-africa [Accessed 30 May 2020].

Wrisdale, L., Mokoena, M.M., Mudau, L.S. and Geere, J.A., 2017. Factors that impact on access to water and sanitation for older adults and people with disability in rural South Africa: An occupational justice perspective. Journal of Occupational Science, 24(3), p. 259-279.

Young, S.L., Boateng, G.O., Jamaluddine, Z., Miller, J.D., Frongillo, E.A., Neilands, T.B., Collins, S.M., Wutich, A., Jepson, W.E. and Stoler, J., 2019. The Household Water Insecurity Experiences (HWISE) Scale: development and validation of a household water insecurity measure for low-income and middle-income countries. B.M.J. global health, 4(5), p. 001750.

Zaied, R.A., 2018. Development of water saving toilet-flushing mechanisms. Applied water science, $8(2)$, p. 53.

Zawahri, N. A., 2017. Water Security in the Middle East and North Africa. In Humanities and Future. 